Int. J. Electrochem. Sci., 15 (2020) $8386-8396$

International Journal of

ELECTROCHEMICAL

SCIENCE

WWW.electrochemsci.org

\title{
Electrochemical Determination of Gemifloxacin Mesylate in Commercial Tablets and Biological Fluids By Differential Pulse Polarography
}

\author{
Salma A. Al-Tamimi*, Amal M. Al-Mohaimeed, Nawal A. Alarfaj, Fatma A. Aly \\ ${ }^{1}$ Department of Chemistry, College of Science, King Saud University, P. O. Box 22452, Riyadh \\ 11495, Saudi Arabia \\ ${ }^{2}$ Department of Pharmaceutical Analytical Chemistry, Faculty of Pharmacy, Mansoura University, \\ Mansoura 35516, Egypt \\ "E-mail: $\underline{\text { satamimi@ksu.edu.sa }}$
}

doi: $10.20964 / 2020.09 .19$

Received: 4 February 2020 / Accepted: 10 July 2020 / Published: 10 August 2020

\begin{abstract}
An ultrasenstive electrochemical probe was suggested for the estimation and quantification of gemifloxacin mesylate (GFX) in its pharmaceutical products and biological media. Differential pulse (DPP), Cyclic voltammtery (CV) and Alternative current $\mathrm{AC}_{\mathrm{t}}$ were exploited to investigate the electrochemical nature of GFX. Over the $\mathrm{pH}$ range of 2.6-10, the investigated drug demonstrated significant cathodic peaks. The best polarographic response was achieved in acetate buffer (pH 5), scan rate $15 \mathrm{mV} \mathrm{s}^{-1}$ and pulse amplitude $-90 \mathrm{mV}$. The outcome linearity was $1.59 \times 10^{-6}-2.70 \times 10^{-5}$ $\mathrm{mol} \mathrm{L}^{-1}\left(0.77-13.1 \mu \mathrm{g} \mathrm{mL}^{-1}\right)$. The limits of detection and quantification were determined as $2.89 \times 10^{-}$ 7 and $8.76 \times 10^{-7} \mathrm{~mol} \mathrm{~L}^{-1}$, respectively. The proposed electrochemical approach was validated and successfully used to quantify the selected drug in different media. The outcome results were compared with others obtained from reference method and displayed good accuracy and precision agreement.
\end{abstract}

Keywords: Gemifloxacin mesylate; Differential pulse polarography; Commercial products; Biosamples

\section{FULL TEXT}

(C) 2020 The Authors. Published by ESG (www.electrochemsci.org). This article is an open access article distributed under the terms and conditions of the Creative Commons Attribution license (http://creativecommons.org/licenses/by/4.0/). 